\title{
Book Reading Among College Students in Pusan, Korea
}

\begin{abstract}
This survey shows that Pusan College students have developed commendable reading habits in the relatively few years since their country began to move toward modernity. They spend a good portion of their free time reading; they read many books high in literary and social content, and they show a genuine interest in books by foreign authors. Their criticisms regarding the mediocrity of the Korean publishing industry and the restrictive practices of most of their libraries are a testimony to the fact that they have begun to look upon books as essential to their personal and national development.
\end{abstract}

$\mathrm{T}$ HIS STUDY DEALS with the book reading habits of college students in Pusan, Korea. It seeks to learn why these students read books, where they get them, the kind of books they read, and the special situations in their country which either discourage or impede the practice of good book reading habits.

The data on which this report is based were gathered during Korean Book Reading Week in September 1967. Six hundred students, representing each of five junior and three four-year colleges in the Pusan area were interviewed. Respondents were selected at the various campuses on the basis of their availability with no attempt at systematic sampling. Of the six hundred students approached, fifteen refused to be interviewed because they were afraid the

Mr. Lewis is a Research Analyst with the U.S. Information Agency, Room 905, 1750 Pennsylvania Avenue, N.W., Washington, D.C. interview would make them late for class. Twenty-five questionnaires were discarded because they were incomplete.

\section{FINDINGS}

\section{Reading Habits}

According to survey results, most Korean students in Pusan ( 80 per cent) read books for self-improvement. A minority ( 13 per cent) read for entertainment, and 7 per cent do so to supplement college courses.

A substantial majority ( 73 per cent) read one to two books a month. Of those who read more, 17 per cent report reading between two and five books monthly, 4 per cent read more than five, and about 6 per cent read fewer than one book a month.

For a majority of the students ( 65 per cent) most of the reading takes place in their respective homes. Of the remaining respondents 25 per cent said they read "anywhere," 8 per cent read in li- 
braries, and 2 per cent in the crowded buses or streetcars.

Although only 8 per cent of all respondents said they do most of their reading in libraries, 58 per cent said they do some of their reading there. Among the students who do some of their reading in libraries, 33 per cent use only their own school library, 14 per cent use their own school library and the public library, 8 per cent use their own school library and the USIS library in Pusan, and 3 per cent use their own school library and the libraries of other schools.

Less than half ( 41 per cent) of the occasional library users said they go to the library once or twice a month, while a slightly larger percentage (43 per cent) said they attend more frequently. Sixteen per cent did not answer the question.

\section{Sources of Books}

The chief sources of books, mentioned by 48 per cent of all respondents, were the various libraries available to the student. $^{1}$ This was followed by 39 per cent who said they buy their books from bookstores, 34 per cent said they borrow them from their friends, and 10 per cent said their chief source of books were the small personal libraries they maintain in their own homes. Two per cent mentioned book gifts they receive from friends and relatives.

Of the 219 respondents who said they get their books through bookstores 78 per cent said they usually buy two books a month, ${ }^{2}$ while 9 per cent buy fewer,

\footnotetext{
${ }^{1}$ This figure is not in contradiction with the 58 per cent who said they use the library some of the time, for many of the latter go to the library for purposes other than reading. Thus, when students were asked: "For what reason do you go to the library?" 41 per cent said they go for amusement, 26 per cent for culture, 18 per cent to study, and 10 per cent for other purposes. Five per cent did not answer.

${ }^{2}$ The average cost of a book is 500 won (about $\$ 1.75)$.
}

and 13 per cent buy more. Furthermore, of the student book buyers about one-third (39 per cent) spend between 20 and 50 per cent of their monthly allowance on books, ${ }^{3}$ while 37 per cent spend less and 21 per cent spend more. Three per cent of the respondents did not answer the question.

Almost all respondents (94 per cent) said they maintained their own personal library. Seventy-five per cent of these book owners said their personal library consisted of about one hundred books, 10 per cent between one hundred and two hundred books, and 10 per cent reported owning more than two hundred books. Regarding content 59 per cent said most of their books dealt with cultural subjects, 13 per cent said most of their books were academic books, 12 per cent described the bulk of their personal books as "books in line with my major interest," 6 per cent said their books were mostly amusement books, and 10 per cent gave no answer.

\section{Kind of Books Read}

Approximately 427 respondents reported they were currently reading a total of 243 separate titles including thirteen magazines. Of these 243 titles 45 per cent were fiction and 55 per cent nonfiction. Forty-four per cent of the titles were written by Koreans, and 56 per cent by non-Koreans (Table 1).

Of the 111 fiction titles, Koreans authored only 16 per cent; of the remainder, Americans authored 37 per cent; French, British, and Russian writers authored 7 per cent each; Japanese writers authored 5 per cent; and German authors produced 3 per cent. Sixteen per cent were either anthologies or short stories written by a variety of foreign authors, or foreign books whose national

\footnotetext{
${ }^{3}$ The average monthly student allowance is 2,500 won, or approximately $\$ 8.00$.
} 
TABLE 1

Types of Books Which Students Were Currently Reading by Content and Nationality of Author

\begin{tabular}{|c|c|c|c|c|c|}
\hline Content & Korean & U.S. & $\begin{array}{l}\text { Other } \\
\text { Foreign } \\
\text { Authors }\end{array}$ & $\begin{array}{l}\text { Anthologies } \\
\text { \& Unknown }\end{array}$ & Total \\
\hline Fiction & 18 & 41 & 34 & 18 & 111 \\
\hline \multicolumn{6}{|l|}{ Non-Fiction } \\
\hline Essay & 46 & 0 & 2 & 0 & 48 \\
\hline Social Science & 7 & 13 & 4 & 0 & 24 \\
\hline Philology & 1 & 3 & 6 & 2 & 12 \\
\hline Biography & 2 & 2 & 6 & 0 & 10 \\
\hline \multirow[t]{2}{*}{ Other } & 32 & 0 & 2 & 4 & 38 \\
\hline & 106 & 59 & 54 & 24 & 243 \\
\hline
\end{tabular}

authorship could not be determined from the data (Table 2).

Of the 132 nonfiction titles, Koreans authored 67 per cent and foreign writers 33 per cent. More than half ( 52 per cent) of the Korean nonfiction titles were "essays," small volumes consisting of popular commentaries on aesthetic, moral, and educational subjects, and written primarily by women writers.

Among the remaining Korean authored nonfiction titles, 8 per cent were in the field of social science, 2 per cent were biographies, 1 per cent philology, and 36 per cent other categories including magazines, anthologies, and books whose Korean authorship was unknown.

Of the forty-four foreign nonfiction books which the students were reading,

TABLE 2

Foreign Books Which Students Were Currently Reading by Content and Nationality of Foreign AUthor

\begin{tabular}{lrrr}
\hline \hline Foreign Nations & Fiction & Nonfiction & Total \\
\hline United States & 41 & 18 & 59 \\
Germany & 4 & 8 & 12 \\
France & 8 & 3 & 11 \\
Great Britain & 8 & 3 & 11 \\
USSR & 8 & 1 & 9 \\
Japan & 6 & 1 & 7 \\
Anthologies & 11 & 6 & 17 \\
Unknown & 7 & 4 & 11 \\
& -93 & - & 137 \\
\hline
\end{tabular}

twenty titles dealing primarily with social science were written by Americans; eight, consisting of biographies, philosophy, and social science, were written by Frenchmen; and six titles, of which five were in philosophy and one was a biography, were written by Germans. Of the remainder, three titles were by Englishmen, two by Scandinavian writers, and five were collections of biographies by various foreign writers.

Near the end of the questionnaire respondents were asked to name their favorite author. One hundred and fortyfive writers were mentioned. Most popular of all was the American novelist, Pearl Buck, with 132 mentions (Table 3 ). Next was Park Kyong-Ni, Korean female essay writer, with 117 mentions (Table 4). In third and fourth places were the American novelist, Ernest Hemingway with sixty-five votes, and Yi Kwang-Soo, male Korean novelist, with sixty-four (Table 4). The favorite non-American foreign author was the Russian novelist, Tolstoy (Table 5).

By nationalities, 55 per cent of all authors mentioned were Korean. Of the remainder, 13 per cent were American, 9 per cent were French, 8 per cent British, 4 per cent Russian, 4 per cent German, 1 per cent Japanese, and 6 per cent represented various other foreign countries. 
TABLE 3

Ten Most Popular American Authors ${ }^{\circ}$

\begin{tabular}{lrlc}
\hline \hline \multicolumn{1}{c}{ Authors } & Respondents & \multicolumn{1}{c}{ Authors } & Respondents \\
\hline Pearl Buck & 132 & J. Kennedy & 2 \\
E. Hemingway & 65 & W. Faulkner & 2 \\
M. Mitchell & 24 & K. Mansfield & 2 \\
J. Steinbeck & 20 & B. Russell & 2 \\
O. Henry & 6 & H. Keller & 2 \\
\hline
\end{tabular}

- A total of 19 American authors were mentioned by 265 respondents who answered the question: "Who is your favorite author?"

TABLE 4

Ten Most Popular Korean Writers by Sex and Book Content ${ }^{\circ}$

\begin{tabular}{lllc}
\hline \hline \multicolumn{1}{c}{ Author } & Sex & Type & Mentions \\
\hline Park Kyong-Ni & Female & Essay & 117 \\
Yi Kwang-Soo & Male & Fiction & 64 \\
Mo Yoon-Suk & Female & Essay & 44 \\
Yi Ok-Nyong & Male & Essay & 39 \\
Kim Hyong-Suk & Male & Essay & 33 \\
Choi Jung-Hi & Female & Essay & 22 \\
Yong Bi-Suk & Male & Fiction & 26 \\
Kang Shim-Jae & Female & Essay & 18 \\
Bank Jong-Hwa & Male & Fiction & 15 \\
Park Hwa-Song & Female & Fiction & 14 \\
\hline
\end{tabular}

- Names suggested by answers to question: "Who are your favorite Korean authors?" Complete tally showed; 348 respondents mentioned 52 male writers; and 272 respondents mentioned 28 female writers.

TABLE 5

Ten Most Popular Non-American and NON-Korean AUTHORs ${ }^{\circ}$

\begin{tabular}{lclr}
\hline \hline \multicolumn{1}{c}{ Authors } & Respondents & \multicolumn{1}{c}{ Authors } & Respondents \\
\hline Tolstoi & 35 & J.-P. Sartre & 11 \\
Dostoevski & 26 & Goethe & 8 \\
S. Maugham & 14 & S. Sagin & 8 \\
A. Gide & 11 & Mira Mizko & 6 \\
deMaupassant & 11 & A. Camus & 5 \\
\hline
\end{tabular}

-A total of 46 non-American foreign authors were mentioned by 71 respondents in answer to the question: "Who are your favorite authors?"

\section{Student Suggestions}

One hundred and sixty-nine of the 560 respondents made suggestions for improving book publishing in Korea. The suggestion made most frequently (53 per cent) was that the publishers should present books with better content. Other suggestions included the recommendation that books contain fewer typographical errors ( 22 per cent), that foreign books should be better translated (16 per cent), and miscellaneous suggestions ( 9 per cent) (Table 6 ). 
TABLE 6

Student Suggestions for Improving Book Publishing in Korea

\begin{tabular}{lc}
\hline \multicolumn{1}{c}{ Suggestion } & Frequency \\
\hline & Per Cent \\
Publish books with better content & 53 \\
Fewer typographical errors & 22 \\
Better translations & 16 \\
Better constructed books & 4 \\
Fewer Japanese books & 2 \\
Footnotes for difficult words & 2 \\
Other suggestions & $\frac{2}{100 \%}$ \\
\hline
\end{tabular}

TABLE 7

Student Suggestions for Improving Libraries in Korea

\begin{tabular}{lc}
\hline \hline \multicolumn{1}{c}{ Suggestion } & Frequency \\
\hline & Per Cent \\
Make libraries more pleasant and comfortable & 35 \\
Increase number of books & 27 \\
Permit books to circulate & 20 \\
Arrange books on open shelves & 12 \\
Longer library hours & 3 \\
Better classification of books & 2 \\
Others & 1 \\
& $100 \%$ \\
\hline
\end{tabular}

One hundred and ninety-four respondents answered the question: "What suggestions do you have for improving the libraries in Korea?" The four suggestions most frequently offered were "Make libraries more pleasant and comfortable" (35 per cent), "Increase the number of books in the libraries" ( 27 per cent), "Permit books to circulate" ( 20 per cent), and "Arrange books on open shelves" ${ }^{\prime}$ ( 12 per cent) (Table 7 ).

\section{Discussion}

The findings of this study show that the college students interviewed in $\mathrm{Pu}$ san have a healthy interest in books. They spend a good portion of their free time reading, they read many books

\footnotetext{
4 Of the eight schools of higher education in Pusan, only one, Pusan Teacher's College, keeps its books on open shelves.
}

high in literary and social content, and they show a commendable interest in books by foreign authors.

What is surprising about this healthy student interest in books is that it is largely self-generated, that it has developed with little or no support from the very institutions which are, or should be, interested in book reading: universities, book publishers, bookstores, and libraries. The remainder of this paper, therefore, will deal with the failure of these institutions adequately to support book reading among college students.

\section{Book Reading in Colleges}

The first of these weaknesses, located in the colleges themselves, is the general failure of professors, as reported by many of the respondents, to emphasize 
the importance of books in the learning process. By pointing out this failure the author is not suggesting that Korean colleges and universities adopt in toto Mortimer Adler's dependence upon The Great Books as the chief materials of education. It appears rather that teachers should recognize that new knowledge emerges from old and that the repository of old knowledge is books. If this fact were more widely accepted, there would be fewer college courses based entirely upon classroom notes taken by the professor when he was a student, and wider use of outside readings, a practice which is largely ignored.

\section{Korean Book Publishers}

A second weakness can be attributed to the Korean publishers for their failure to provide the kinds of books which might contribute more fully to student development. This criticism was voiced, not only by the students, as shown in the findings, but by others as well. Thus, in a survey of book publishing in Korea, reported by Dae Ke-min in the Korean Herald, of April 20, 1967, it was disclosed that of the total books published in 1966, 61 per cent were comic books, 20 per cent were "ponies" (book aids for passing school examinations), and only 19 per cent, "regular" books. In other words less than 20 per cent of all the books published in 1966 could be considered suitable and useful for the future leaders of the country.

It is quite true that comic books and "ponies" are money-makers, but publishers should have a higher motivation than the mere making of money. They are not mere merchants; they are both guardians of their country's culture and copilots in their country's drive toward progress. Publishers could contribute greatly to this drive by bringing out the kind of books students want and need.

Publishers might well respond that such a program requires money they do not have. Assuredly one cannot expect a publisher, or anybody else for that matter, to contribute to his society at the expense of his own existence. But the problem is not insurmountable. Production processes can be made more economical, subsidies might be sought from the government, or costs might be cut by the universally accepted technique of improving sales. By the use of these approaches-or others-it should be possible for publishers to turn out better books and make a reasonable profit at the same time.

\section{Bookstores}

A third demerit might be meted out to the Korean bookstores for their failure to serve more adequately the book reading interests of students. To begin with, few of the twenty or so which exist in Pusan-not counting about fifty or more small book stalls-are larger than a medium-sized living room, or have as many as one thousand books on their shelves. Furthermore, the stock of most of the bookstores is arranged neither by subject matter nor by author, but by the order-or disorder-in which they arrived from the publisher. Finally, few if any of the bookstores utilize lists, displays, or, most important of all, book salesmen who know something about the books they are offering for sale. All this adds up to a mediocrity of operation which not only limits profits, but also serves to discourage bookstore use by students.

\section{Korean Library System}

A concluding series of criticisms can be made of the Korean library system. One of these, pointed out by the students themselves, is the meagerness of library book collections, estimated by reliable observers to average only 25,000 volumes for each college library in Ko- 
rea. ${ }^{5}$ Almost all Korean librarians answer this complaint by pleading poverty. "The library," they say, "would buy more books if it had more money." Although this defense is partially true, it is also true that college authorities are insufficiently aware of the indispensability of books in a modern educational institution, and that if they were, they could seek more vigorously-and get-additional funds.

Students also criticized their college libraries for failure to provide suitable facilities for reading. The allegation is true. What the visitor sees when he enters the average library are bare walls, uncovered windows, a scattering of crude benches and desks, and, in the wintertime, freezing temperatures, because none of the Korean libraries are heated. Korean college students, like Koreans in general, are hardy people and quite accustomed to a hard life. But a student's ability to tolerate discomfort should not blind the library authorities to the need to provide facilities which are at least basically comfortable and attractive.

Students also complain that they are not permitted to take books out of the library. Librarians say that the reason for prohibiting book circulation-except to professors and special students-is that the practice would strongly limit the use of the library books, for if a book is in circulation, it is not available for use in the library. The reasoning is spurious. Every library has a large number of books for which there is only occasional demand. These books could certainly be permitted to circulate with hardship to none. The books for which there is a strong demand present a different problem. But even these books could circulate overnight and during

${ }^{5}$ Also pointed out by competent observers is the fact that approximately half of each college collection consists of old books donated by interested foreigners, especially Americans. weekends, when students cannot read them in the library anyway. The point which many Korean librarians fail to realize is that books are to be used, and if this is not possible, or if it is made difficult, then there is little excuse for the existence of the book.

The argument offered by librarians to support their practice of keeping their books locked up, a final student complaint, is that this method prevents stealing. This is a highly exaggerated fear. Few books are likely to be stolen if common-sense precautions are taken. Some of these which have proved effective in other libraries include a clearly stamped indication of library ownership, a single passageway for those entering or leaving the library, and a requirement that patrons check briefcases and overcoats before entering the library. If none of these methods work, of course, Korean librarians might well accept the point of view of other progressive librarians all over the world, namely, that books are expendable. If the loss by theft is minimal, it should be accepted as one of the normal costs of library operation.

\section{Conclusion}

This study has shown that college students in Pusan have a healthy interest in books. They appear to realize that they have much ground to make up in modernizing their nation, and that books, more than anything else, would help enable them to do so. The study has also shown that the exercise of this healthy book reading interest is being held back by basic shortcomings of the very institutions responsible for student education through book reading. In the interest both of the college students and of Korea as a nation, one can hope that these shortcomings will be overcome. For, in the movement from traditionalism to modernity, there is nothing more important than books. 